\title{
Analysis of the Employment Efficiency of Applied College Students with Colleges in Zhejiang as Examples*
}

\author{
Jie $\operatorname{Lin}^{1}$ \\ Zhejiang University of \\ Water Resources and \\ Electric Power
}

\author{
Kang $L i^{2}$ \\ Jianlin $\mathrm{Pan}^{3}$ \\ Zhejiang University of Water \\ Resources and Electric Power
}

\begin{abstract}
While colleges and universities keep providing more applied talents to the job market, they cannot ignore the importance of cultivating their employability and improving their employment efficiency and quality. This paper takes the regular college and junior college in Zhejiang as examples, and uses the DEA model to estimate the employment efficiency and job seeking efficiency of their graduate. The results of the model indicate that, for applied college students, their employment and job seeking efficiency is not at the optimal level. Through Tobit model regression, this paper further analyzes how other potential factors affect the employment efficiency and job seeking efficiency and the degrees of these impacts. The results show that: all the factors to employability investment and employment output can be the reasons for the low employment efficiency and job seeking efficiency of college students; the employment efficiency is easily affected by the family financial situation and is positively correlated to family social capital; and the job seeking efficiency is more susceptible to gender, number of practices and level of effort in job seeking. In the end, this paper proposes suggestions on how to improve the employability of college students from the perspective of education supply.
\end{abstract}

\section{Keywords}

Applied Education • College Students • Employment Efficiency • Job Seeking Efficiency

\footnotetext{
* Support for this research was provided by Project of Zhejiang Educational Commission (Grant No. Y201738291), Philosophy and Social Sciences Program of Hangzhou City (Grant No. Z18JC105), Project of the Zhejiang Soft Science Research plans (Grant No. 2018C35064), Zhejiang Philosophy and Social Science Planning Project (Grant No.16NDJC308YBM).

${ }^{1}$ Correspondence to: Jie Lin $(\mathrm{PhD})$, School of Economics and Management, Zhejiang University of Water Resources and Electric Power, Hangzhou 310018, China. Email: linjielinjie1@163.com

${ }^{2}$ School of Economics and Management, Zhejiang University of Water Resources and Electric Power, Hangzhou 310018 ,

China. Email: likang312@163.com

${ }^{3}$ School of Economics and Management, YiWu Industrial \& Commercial College, Yiwu 322000, China. Email: jianlin9@163.com
} 
As the most dynamic youth group, college students carry the important task of making knowledge innovations and promoting social progress. Their employment quality is an important indicator of the higher education level in a country. The proportion of adults with college education in an area is significantly correlated to the local population growth in the future (Winters, 2011), so college graduates have always been the group that the government attaches great importance to in terms of employment. In the job market for college students, employers are the demand side and colleges and universities are the supply side. However, since the higher education in China shifted from elite education to mass education, the job market for college students has been short of technically skilled talents and overfilled with theory-oriented talents, and the employment quality of college students has not been optimistic. The structural contradictions in the supply of talents have put the employment of college students in serious trouble. With the acceleration of industrialization, urbanization and agricultural modernization and the rise of strategic emerging industries, the overall demand for high-skilled talents is becoming even more urgent in the society (Lu, 2013), and the employment of college students has been in difficulty on a long-term and persistent basis. In addition, according to the Employment Blue Book: 2018 Chinese College Graduates Employment Annual Report published by MyCOS Research Institute, the quit rates of graduates from regular and vocational college within the first half of the year were $23 \%$ and $42 \%$, which are basically flat compared with those in 2016 (24\% and 43\%, respectively), indicating that employment of college students is not stable. This kind of instability exerts negative impacts on personal career development, stable operation of enterprises and even the social and economic situation (Liu and Zhu, 2017; Zhou, 2012).

The academic field has long been discussing the employment difficulties and low employment quality of college students. The general opinion is that the extensive development of colleges and universities makes the students' abilities and quality unable to meet the needs of social development. Researchers have realized that it is necessary to find the root causes on the supply side of the job market for college students - from the law or system of education in colleges or universities. For example, Zeng (2004) analyzed the causes of the current employment difficulties of college students from the perspective of system. He believed that the institutional segmentation like urban-rural segmentation and industrial monopoly are the important factors affecting the employment of college students. Wang (2006) believed that the higher education enrollment expansion in China results in the oversupply of human resources in the job market and makes some college students unable to get employed in time; Lin and Hong (2014) focused on the employment inequality of college students and pointed out that college students should have equal and fair employment rights, opportunities, competition and outcomes in the process of initial employment after graduation. Wang (2016) pointed out the problems in the cultivation of undergraduate talents, such as unclear goals, homogenization of talents and conservative orientation. In addition, a large number of studies have also indicated that factors such as human capital (Romailis, 2004; Hausmann, Hwang \& Rodrik, 2007), social capital (Rees, 1966) and personality traits (Barrick and Mount, 1991; Nicholson, 1996; Heckman, 2000; Heckman and Rubinstein, 2001) are also decisive factors affecting individuals' employment performance. It can be seen that the employment difficulty of college students involves many aspects and is affected by both external and internal factors. How to improve the employment quality of college students while maintaining the employment increase is still a major problem in Chinese society (Chen and Wan, 2017; Zhang and Xu, 2015; Wu and Zhao, 2010). 
The Outline of the National Medium- and Long-Term Programme for Education Reform and Development (2010-2020) emphasizes that higher education should optimize its structure and expand the training scale of applied, interdisciplinary and skilled talents. In the new era, while laying the foundation for the all-round development of students, Chinese universities and colleges should also highlight the training of practical abilities so as to solve the difficulties in the current employment market (Li, 2012), which is why applied education is called for in China. Applied education, as a combination of higher education and productive labour, pays more attention to the practice of productive labour and attaches greater attention to the integration of knowledge and production practice than regular higher education (Liu, Guo, Li \& Ding, 2013; Knight, 2001). It is an innovative exploration of higher education. Now promoting applied education and improving its status are extremely urgent. However, under the influence of the idea of educational background foremost in China, the public has a misunderstanding about applied education. At the same time, due to the late start of applied education, the education department has not developed a mature idea about how to cultivate applied talents. There is still a long way to go. Therefore, this paper intends to conduct a survey among the training targets of applied education in order to provide some useful suggestions for optimizing the talent structure, increasing the employment of college students and improving their employment quality.

At present, the research on the employment quality of labourers has received sufficient attention at home and abroad, but there is still disagreement on how to improve the quality. For example, the concept of employment quality and its content are understood differently in different areas around the world (Clark, 2005; Kalleberg and Vaisey, 2005). This paper believes that the employment quality should be a comprehensive reflection of the employment of college students in terms of both quality and quantity. The "quality of employment" is the subjective and objective evaluation of the employment results by the employed, which can be characterized by employment satisfaction, corporate loyalty, coincidence with the career expectations and relevance between job and major. The "quantity of employment" refers to the employment structure. Where the employment is saturated, the supply and demand of college students are balanced in the job market. In the context of mass education, colleges and universities, especially the local colleges with a short history, are facing new challenges like how to maintain and improve the quality of education and teaching. In this regard, many researchers explored the ways to improve the employment quality from the demand side (Alm and Winters, 2009; Groen, 2004; Ma and Pan, 2013), but in recent years, more and more scholars have realized it is more important to discuss the training of employability on the supply side based on the market demand (Cuyper, Raeder, Van der Heijden \& Wittekind, 2012; Cuyper, Mauno, Kinnunen \& Mäkikangasb, 2011; Fugate and Kinicki, 2008; Wittekind, Raeder \& Grote, 2010). There are two approaches on the study of the employability structure at home and abroad: the input-based approach and the output-based approach (Cuyper, Van der Heijden \& Wittekind, 2012). Both approaches view employability as the individual resources needed for individuals to acquire and maintain employment opportunities, but the input-based one emphasizes the factors that increase the employment opportunities, while the output-based one the employment outcomes (Yu, Zheng, Xu \& Yan, 2014). Employment is a dynamic process, and thus employment quality evaluation should also include the transformation process from employability input to output. However, there are few empirical studies on this. Considering that the DEA model used in economics to estimate the conversion efficiency of input and output can well characterize the dynamic transformation process, this paper uses this model to describe the 
quality of the employability input and output transformation of college students and studies the employment quality of applied college students through employment efficiency analysis.

\section{Models and Methods}

\section{Selection of the calculation method for the employment efficiency of college students}

Total factor productivity (TFP) is one of the main tools to explore the sources of economic growth and determine the quality of growth, and an important basis for formulating economic sustainable growth policies. This paper regards the labour market as an independent market, and labour as a product, and uses TFP to measure the employment quality and efficiency of college students. The production function method proposed by Solow (1957), Denison (1961), Jorgenson and Griliches (1967) is one of the most representative traditional TFP calculation methods. However, the traditional TFP assumes that the production technology is completely effective. This method interprets all the growth residuals other than the growth of labour and capital in economic growth as technological progress. In order to solve this problem, the production frontier analysis method came into being. Compared with the traditional methods, this one is closer to reality and can more accurately reflect the actual situation of economic growth. In addition, frontier analysis can separate the influencing factors from the rate of change, which also helps deeply analyze the main root causes affecting the economic growth trajectory, and that is why it is widely used. Due to the different ways to construct the frontier, the frontier analysis method can be divided into stochastic frontier analysis (SFA) based on the parametric model and data envelopment analysis (DEA) based on the nonparametric model.

The DEA method is adopted in this paper. Unlike the SFA method, DEA does not need to assume the functional form in advance, nor does it have to test the validity and rationality of the parameter estimation. It can evaluate indicators of different dimensions, and does not need to subjectively assign relative weights of the indicators, and moreover, it can deal with multiple inputs and outputs, making it highly objective and convenient. Tone (2001) proposed the non-radial and non-angled SBM (Slacks-based Measure of Efficiency) model. It puts slack variables directly into the objective function, which further solves the efficiency overestimation problem of the conventional CCR model when there exists non-zero slack of input or output or the inaccurate efficiency estimation problem of the BCC model due to its neglect of one aspect of the input or output. The SBM model has options for constant returns to scale (CRS) and variable returns to scale (VRS). Obviously, VRS is more in line with the actual situation of the employment market for college students, so the SBM-VRS model is used in this paper to calculate the employment TFP of college students.

\section{Input and output indicators}

Applied college students who are graduating and have graduated from the economics and management majors are the main subjects of this paper. Since these respondents include those who have been employed and are looking for jobs, this paper constructs an input-output framework for each group of them to measure the employment efficiency and job seeking efficiency. The first step is to design the input and output indicators of employment efficiency and job seeking efficiency and develop the questionnaire based on the purpose of this 
paper. Through the analysis of the data collected from the trial questionnaire, the study further considers the appropriateness of each question, and adjusts and modifies them according to the analysis results of the test data and the opinions of the colleges and experts to finalize the formal questionnaire (See Table 1).

Input indicators: In the studies of employment results, a large number of scholars directly used job satisfaction as the variable. However, job satisfaction is only a subjective evaluation indicator in the evaluation of employment results, and reflects only an overall satisfaction evaluation of the current job by an employee. Without the degree of competition in the job seeking environment faced by the job seekers and the level of effort made by them in the job seeking process, the employment results cannot be accurately and comprehensively reflected. Therefore, this study cites the concept of employment decision satisfaction (Weng, Liu, Wu \& Wang, 2016) as a subjective indicator of the employment results of college students in the job seeking process, and the concept of job-seeking confidence (Shen, 2013) as a subjective indicator of the job seeking results in the job seeking process, and then introduces such objective indicators as "major and job matching degree, development prospects of the company, work environment of the company, salary, other benefits, and comparison with other students" to form a more comprehensive employment result evaluation system. Among these indicators, employment decision satisfaction refers to how satisfied the employed person feels about this employment decision, and the higher the satisfaction, the better the employment result will be. Job-seeking confidence can reflect how satisfied the job seeker feels in the job seeking process. If the job seeker feels more optimistic and confident about the employment result, he or she will feel more satisfied with the job seeking process.

Output indicators: This paper uses the self-assessment on each aspect of employability by the employed to reflect the different aspects of the talent training system, and as the input indicator of employment efficiency and job seeking efficiency of college students. The indicator system uses the USEM model revised jointly by Peter Knight and Mantz York, which is widely referenced in the research on employment competitiveness (York and Knight, 2004). This model mainly includes four components: subject understanding (understanding of specialized knowledge, awareness of the major development prospects and application of specialized knowledge), skills (professional skill, foreign language skill, problem solving skill, communication skill, information processing skill and interpersonal skill), self-efficacy (confidence, goal planning, perseverance, achievement motivation and sense of responsibility) and meta-cognition (self-regulation, learning and innovation abilities). Among them, subject understanding is the understanding of specialized knowledge; skills include general skills and professional skills required for work; self-efficacy is mainly manifested in confidence; and meta-cognition is mainly about self-reflection. These four elements are not independent of each other, but rather interconnected and interacting.

Factor analysis model: The values of employment efficiency and job seeking efficiency measured in this paper are truncated data greater than 0 . With such censored data, the linear regression estimation includes additional computational complexity problems, and the censored samples cannot represent the population, so the ordinary least squares regression will produce inconsistent parameter estimates. If the least squares model is established for regression directly with the efficiency values as the dependent variables, the estimates of the 
Lin, Li, Pan / Analysis of the Employment Efficiency of Applied College Students_— With Colleges in Zhejiang as the...

parameters will be different. Therefore, this paper selects the Tobit model, which is applicable to the employment efficiency and job seeking efficiency, to perform empirical test on the driving factors.

Table 1

Input and Output Indicators of Employment Efficiency and Job Seeking Efficiency of College Students

\begin{tabular}{|c|c|c|c|}
\hline Category & State & Input & Output \\
\hline $\begin{array}{l}\text { Job seeking } \\
\text { efficiency }\end{array}$ & Unemployed & $\begin{array}{l}\text { subject understanding, } \\
\text { skills, self-efficacy, } \\
\text { meta-cognition }\end{array}$ & $\begin{array}{l}\text { subjective indicator (job-seeking confidence), } \\
\text { objective indicators (time spending on job- } \\
\text { seeking) }\end{array}$ \\
\hline $\begin{array}{l}\text { Employment } \\
\text { efficiency }\end{array}$ & Employed & $\begin{array}{l}\text { subject understanding, } \\
\text { skills, self-efficacy, } \\
\text { meta-cognition }\end{array}$ & $\begin{array}{l}\text { subjective indicator (employment decision } \\
\text { satisfaction), objective indicators (major and job } \\
\text { matching degree, development prospects of the } \\
\text { company, work environment of the company, } \\
\text { salary, other benefits, and other students' work) }\end{array}$ \\
\hline
\end{tabular}

The Tobit model is derived from the MLE estimation model proposed by Tobin. It is a standard censored model and also known as the sample selection model or the limited dependent variable model. It is a value model in which the dependent variables satisfy certain constraints. Different from the discrete model or the continuous variable model, it is featured with limited dependent variables and consists of two types of equations, one being the selection equation that represents the constraint, and the other the continuous variable selection equation that satisfies the constraint. The general form of the Tobit model is:

$$
\mathrm{y}_{i}=\beta x_{i}+u_{i}
$$

where, $y_{i}$ is the efficiency score vector, $x_{i}$ the influencing factor vector and $u_{i}$ the error term vector.

\section{Employment efficiency analysis of college students}

Zhejiang Province, as a major province that actively promotes educational reform, has made great achievements in applied education. This study provides a great number of survey samples. Using the snowball sampling method, the survey team selected Zhejiang University of Water Resources and Electric Power, Ningbo University of Technology, Zhejiang University of Technology, Zhejiang College of Zhejiang University of Technology, Zhejiang Gongshang University Hangzhou College of Commerce, Zhejiang Chinese Medical University Binjiang College, China Jiliang University College of Modern Science and Technology, Zhejiang University of Finance and Economics Dongfang College, Taizhou University, Lishui University and Zhejiang University of Science and Technology, etc., as applied regular colleges, where 350 questionnaires were issued, and Zhejiang University of Water Resources and Electric Power, Zhejiang Business College, Zhejiang Vocational Academy of Art, Zhejiang Changzheng Vocational \& Technical College, and Preschool Teacher Education College of Lishui University as higher vocational colleges, where 270 questionnaires were distributed. A total of 620 questionnaires were recovered from both regular and junior colleges. With the invalid questionnaires with logical problems excluded, there were finally 317 and 254 valid questionnaires respectively from regular colleges and junior colleges.

This paper uses the software DEA-Solver Pro 10 to estimate the employment efficiency and job seeking efficiency of each college student decision making unit (DMU). Table 2 shows the statistical analysis of the employment efficiency scores and the redundancy values of the input and output indicators of regular college students employed. 
Tables 3-5 lists the statistical data of the job seeking efficiency of the regular college students not employed, the employment efficiency of the junior college students employed and the job seeking efficiency of the junior college students not employed. This paper finds (as shown in Table 2-5) that on the whole, whether for regular or junior college students or for employment efficiency or job seeking efficiency, the DMUs with the best efficiency scores (1 point) do not take up a high proportion. The number of people who got a score of 1 in regular college employment efficiency, regular college job seeking efficiency, junior college employment efficiency and junior college job seeking efficiency are 48, 0, 18, and 30, respectively, and the average efficiency scores of these four are $0.838407,0.209127,0.5024919$ and 0.442716 , respectively, which indicates that there is still room for improvement in the employment efficiency and job seeking efficiency of both regular and junior college students. On the whole, the overall employment efficiency of regular college students is high, with the average efficiency score being closest to 1 , while the overall job seeking efficiency of regular college students is the lowest, which reflects the fact that students with high educational background tend to have greater psychological pressure and confusion in the job market when encountering setbacks, as they have generally higher employment expectations. The overall employment efficiency of both regular college and junior college students is higher than the job seeking efficiency, which is in line with the psychological characteristics of the students in the job seeking process. Their evaluation on the employment quality is generally lower than that by the employed students.

In addition to efficiency scores, the computational results of DEA-Solver Pro 10 also provide detailed redundancy of each input and output factor, which can be used to analyze whether the input factors are in excess or in shortage. This paper uses the proportion of DMUs whose indicator redundancy value is higher than the average in the total number of DMUs to find the specific reasons for the low employment efficiency and job seeking efficiency of regular college and junior college students. This paper finds that the redundancy of the input and output factors is relatively balanced within the four types of efficiency, indicating that the low employment inefficiency is a realistic problem caused by multiple factors and needs to be paid attention to on both the supply side and the demand side. The quality of talent training in applied universities requires an allround improvement strategy. Regarding the input factors, compared with regular college students, junior college students have better self-evaluation on their awareness of development prospects and goal planning abilities, but colleges and universities tend to give excessive training on skills and meta-cognition. In the job market, junior college students are more likely to have lower overall efficiency due to excessive skill input. It may be because vocational colleges focus on skills and meta-cognition training, which can easily limit students' career choices. From the perspective of output, junior college students have a lower probability of losing job-seeking confidence and a better employment mentality than regular college ones, which is in line with the previously stated fact that regular college students have higher employment expectations. However, judging from the objective indicators of employment results, it is not difficult to find that regular college students have the lowest probability of shortage in objective indicator. This indicates that regular college students have higher objective evaluation of employment once they are employed, which is also the result of cautious career choices by regular college students. 
Table 2

Input-output Redundancy Degree Regarding the Employment of Regular College Students Employed

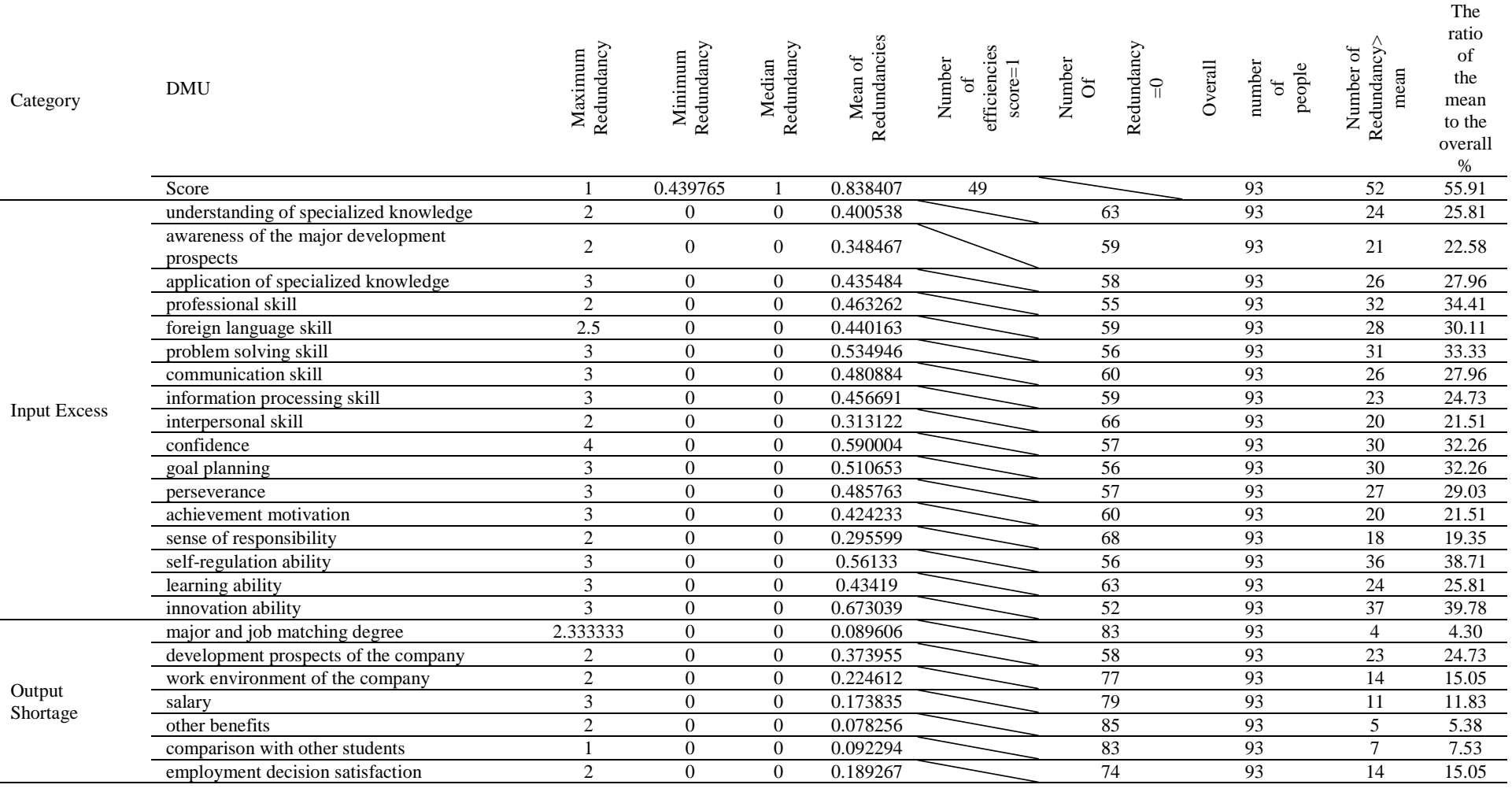


Table 3

Input-Output Redundancy Degree Regarding the Employment of Regular College Students Employed

\begin{tabular}{|c|c|c|c|c|c|c|c|c|c|c|}
\hline \multirow{2}{*}{ 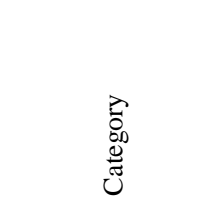 } & $\sum_{\Delta}^{2}$ & 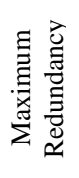 & 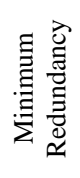 & 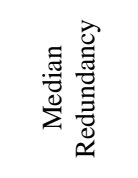 & 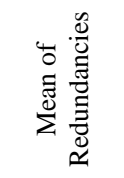 & 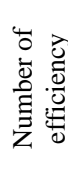 & 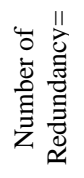 & 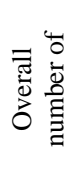 & 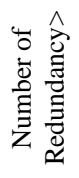 & 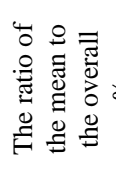 \\
\hline & Score & 1 & 0.08 & 0.1493213 & 0.209127 & 0 & $\mathrm{X}$ & 224 & 73 & 32.59 \\
\hline \multirow{17}{*}{$\begin{array}{l}\text { Input } \\
\text { Excess }\end{array}$} & understanding of specialized knowledge & 4 & 0 & 2 & 1.988098 & & 25 & 224 & 199 & 88.84 \\
\hline & awareness of the major development prospects & 4 & 0 & 2 & 1.988098 & & 18 & 224 & 206 & 91.96 \\
\hline & application of specialized knowledge & 4 & 0 & 2 & 1.961312 & & 19 & 224 & 205 & 91.52 \\
\hline & professional skill & 4 & 0 & 2 & 1.930062 & & 25 & 224 & 198 & 88.39 \\
\hline & foreign language skill & 4 & 0 & 2 & 1.720241 & & 31 & 224 & 191 & 85.27 \\
\hline & problem solving skill & 4 & 0 & 2.000010 & 2.175598 & & 17 & 224 & 207 & 92.41 \\
\hline & communication skill & 4 & 0 & 2.000010 & 2.188991 & & 18 & 224 & 206 & 91.96 \\
\hline & information processing skill & 5 & 0 & 2.000010 & 2.211312 & & 18 & 224 & 204 & 91.07 \\
\hline & interpersonal skill & 4 & 0 & 2 & 2.148812 & & 23 & 224 & 201 & 89.73 \\
\hline & confidence & 4 & 0 & 2.000010 & 2.122026 & & 22 & 224 & 201 & 89.73 \\
\hline & goal planning & 4 & 0 & 2.000010 & 2.148812 & & 16 & 224 & 208 & 92.86 \\
\hline & perseverance & 4 & 0 & 2.000010 & 2.264883 & & 17 & 224 & 207 & 92.41 \\
\hline & achievement motivation & 4 & 0 & 2.000010 & 2.193455 & & 18 & 224 & 206 & 91.96 \\
\hline & sense of responsibility & 4 & 0 & 2.166672 & 2.389883 & & 21 & 224 & 203 & 90.63 \\
\hline & self-regulation ability & 4 & 0 & 2.000010 & 2.224705 & & 18 & 224 & 205 & 91.52 \\
\hline & learning ability & 8 & 0 & 2.000010 & 2.238098 & & 17 & 224 & 205 & 91.52 \\
\hline & innovation ability & 4 & 0 & 2 & 2.046134 & & 19 & 224 & 205 & 91.52 \\
\hline \multirow{2}{*}{ Output Shortage } & time spending on job-seeking & 6 & 0 & 2 & 1.950885 & & 33 & 224 & 191 & 85.27 \\
\hline & job-seeking confidence & 3 & 0 & 1 & 1.010406 & & 66 & 224 & 158 & 70.54 \\
\hline
\end{tabular}


Table 4

Input-output redundancy degree regarding the employment of junior college students employed

\begin{tabular}{|c|c|c|c|c|c|c|c|c|c|c|}
\hline \multirow[t]{2}{*}{ Category } & DMU & 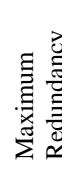 & 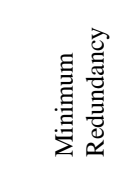 & 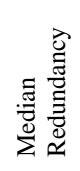 & 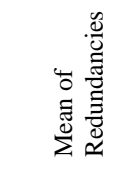 & 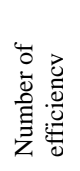 & 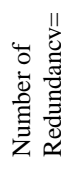 & 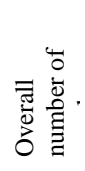 & 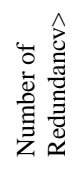 & 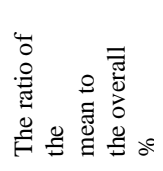 \\
\hline & Score & 1 & 0.2047864 & 0.4 & 0.5024919 & 18 & & 117 & 35 & 29.91 \\
\hline \multirow{17}{*}{ Input Excess } & understanding of specialized knowledge & 3 & 0 & 1 & 1.0911701 & & 32 & 117 & 84 & 71.79 \\
\hline & awareness of the major development prospects & 3 & 0 & 1 & 1.121085 & & 26 & 117 & 89 & 76.07 \\
\hline & application of specialized knowledge & 3 & 0 & 1 & 1.0954435 & & 29 & 117 & 87 & 74.36 \\
\hline & professional skill & 3 & 0 & 1 & 1.1994326 & & 23 & 117 & 91 & 77.78 \\
\hline & foreign language skill & 3 & 0 & 1 & 0.965812 & & 36 & 117 & 81 & 69.23 \\
\hline & problem solving skill & 3 & 0 & 1 & 1.3589757 & & 23 & 117 & 91 & 77.78 \\
\hline & communication skill & 3 & 0 & 1 & 1.3162407 & & 23 & 117 & 90 & 76.92 \\
\hline & information processing skill & 3 & 0 & 1 & 1.3148166 & & 24 & 117 & 90 & 76.92 \\
\hline & interpersonal skill & 3 & 0 & 1 & 1.3276373 & & 22 & 117 & 91 & 77.78 \\
\hline & confidence & 3 & 0 & 1 & 1.3874665 & & 22 & 117 & 93 & 79.49 \\
\hline & goal planning & 3 & 0 & 1 & 1.2279223 & & 25 & 117 & 90 & 76.92 \\
\hline & perseverance & 3 & 0 & 1 & 1.3433068 & & 24 & 117 & 91 & 77.78 \\
\hline & achievement motivation & 3 & 0 & 1 & 1.2735043 & & 28 & 117 & 89 & 76.07 \\
\hline & sense of responsibility & 3 & 0 & 2 & 1.5042735 & & 25 & 117 & 92 & 78.63 \\
\hline & self-regulation ability & 3 & 0 & 1 & 1.3376084 & & 21 & 117 & 93 & 79.49 \\
\hline & learning ability & 3 & 0 & 1 & 1.3589747 & & 22 & 117 & 94 & 80.34 \\
\hline & innovation ability & 3 & 0 & 1 & 1.3247876 & & 22 & 117 & 94 & 80.34 \\
\hline \multirow{7}{*}{ Output Shortage } & major and job matching degree & 4 & 0 & 1 & 1.2222215 & & 27 & 117 & 90 & 76.92 \\
\hline & development prospects of the company & 4 & 0 & 1 & 1.1709416 & & 26 & 117 & 89 & 76.07 \\
\hline & work environment of the company & 3 & 0 & 1 & 1.0370373 & & 28 & 117 & 88 & 75.21 \\
\hline & salary & 4 & 0 & 1 & 1.3005699 & & 28 & 117 & 89 & 76.07 \\
\hline & other benefits & 4 & 0 & 1 & 1.2521375 & & 26 & 117 & 90 & 76.92 \\
\hline & comparison with other students & 4 & 0 & 1 & 1.1965813 & & 26 & 117 & 90 & 76.92 \\
\hline & employment decision satisfaction & 3 & 0 & 1 & 1.1994303 & & 33 & 117 & 83 & 70.94 \\
\hline
\end{tabular}


Table 5

Input-output redundancy degree regarding the job seeking of junior college students not employed

\begin{tabular}{|c|c|c|c|c|c|c|c|c|c|c|}
\hline \multirow[t]{2}{*}{ Category } & DMU & 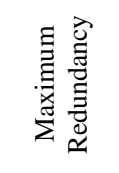 & 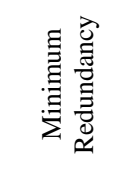 & 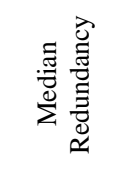 & 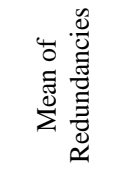 & 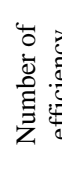 & 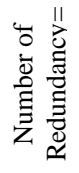 & 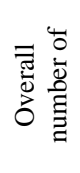 & 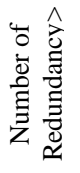 & 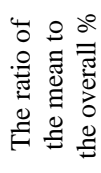 \\
\hline & Score & 1 & 0.1176471 & 0.272686 & 0.442716 & 30 & & 137 & 48 & 35.04 \\
\hline \multirow{17}{*}{ Input Excess } & understanding of specialized knowledge & 2.666667 & 0 & 0.666667 & 0.682593 & & 44 & 137 & 81 & 59.12 \\
\hline & awareness of the major development prospects & 2.880000 & 0 & 0.000000 & 0.352084 & & 85 & 137 & 40 & 29.20 \\
\hline & application of specialized knowledge & 2.666667 & 0 & 0.666667 & 0.675666 & & 44 & 137 & 87 & 63.50 \\
\hline & professional skill & 2.666667 & 0 & 0.666667 & 0.780211 & & 35 & 137 & 89 & 64.96 \\
\hline & foreign language skill & 3 & 0 & 1 & 0.817228 & & 43 & 137 & 89 & 64.96 \\
\hline & problem solving skill & 3 & 0 & 0.333333 & 0.566145 & & 48 & 137 & 56 & 40.88 \\
\hline & communication skill & 3.666707 & 0 & 1.333333 & 1.334313 & & 32 & 137 & 98 & 71.53 \\
\hline & information processing skill & 3 & 0 & 1 & 1.043690 & & 36 & 137 & 96 & 70.07 \\
\hline & interpersonal skill & 3.333333 & 0 & 1.333333 & 1.335780 & & 32 & 137 & 100 & 72.99 \\
\hline & confidence & 3 & 0 & 1.000000 & 1.000891 & & 37 & 137 & 97 & 70.80 \\
\hline & goal planning & 2.000030 & 0 & 0.000000 & 0.427538 & & 76 & 137 & 47 & 34.31 \\
\hline & perseverance & 2.333333 & 0 & 0.333333 & 0.574358 & & 48 & 137 & 57 & 41.61 \\
\hline & achievement motivation & 3.333333 & 0 & 0.666667 & 0.881156 & & 45 & 137 & 87 & 63.50 \\
\hline & sense of responsibility & 2.999800 & 0 & 0.750000 & 0.865922 & & 42 & 137 & 76 & 55.47 \\
\hline & self-regulation ability & 3.000040 & 0 & 0.666667 & 0.834928 & & 35 & 137 & 94 & 68.61 \\
\hline & learning ability & 3.666667 & 0 & 1.333333 & 1.305098 & & 35 & 137 & 101 & 73.72 \\
\hline & innovation ability & 2.666667 & 0 & 0.666667 & 0.727970 & & 40 & 137 & 86 & 62.77 \\
\hline \multirow{2}{*}{ Output Shortage } & time spending on job-seeking & 7 & 0 & 3.999990 & 3.201119 & & 31 & 137 & 101 & 73.72 \\
\hline & job-seeking confidence & 1.999890 & 0 & 0 & 0.081932 & & 123 & 137 & 10 & 7.30 \\
\hline
\end{tabular}


Lin, Li, Pan / Analysis of the Employment Efficiency of Applied College Students_— With Colleges in Zhejiang as the...

But it also verifies the previous statement that they have greater pressure in career choice and employment. In summary, the employment difficulty of junior college students reflect that it is necessary to cultivate and improve their comprehensive skills and promote their overall balanced quality development, and the employment difficulty of regular college students lies in their lack of the right views on employment and choice of career. This paper believes that the immature supply and demand docking platform for the job market of college students is the root cause of the above situation.

\section{Analysis of the influencing factors to employment efficiency}

Note: “*” stands for $\mathrm{p}<0.1$, “**”, $\mathrm{p}<0.05$ and “***”, $\mathrm{p}<0.01$.

From the perspective of colleges and students, existing research and experience have shown that the academic and practical training of students as well as the family environment and personal subjective efforts have influences throughout the formation of employability, the maintenance of employment results, and the transformation from the employability to the employment result. Considering the differences in the behaviours and concepts of job seekers caused by gender in the job market, this paper finally selects gender, number of scholarships received during college, number of social practices during college, monthly family income, family social relations and level of effort in job seeking as potential influencing factors to the employment efficiency and job seeking efficiency of college students. Through the impact analysis of the six factors, this paper further clarifies the ways to improve employment efficiency and job seeking efficiency of college students.

In Table 6, Model 1, 2, 3 and 4 are respectively the employment efficiency of regular college students employed, employment efficiency of junior college students employed, job seeking efficiency of regular college students not employed and job seeking efficiency of junior college students not employed. The employment efficiency of students from applied regular colleges is mainly affected by family monthly income and family social relations; the employment efficiency of junior college students is only affected by family social relations; the job seeking efficiency of regular college students is affected by gender, number of practices and level of effort in job seeking; no impact is observed from these 6 factors on the job seeking efficiency of junior college students.

Table 6

Tobit Regression Results

\begin{tabular}{lcccc}
\hline Variable & Model1 & Model 2 & Model 3 & Model 4 \\
\hline gender & $-0.06(-0.75)$ & $-0.04(-0.70)$ & $-0.04^{*}(-1.71)$ & $-0.11(-1.51)$ \\
Number of scholarships & $-0.01(-0.47)$ & $-0.01(-1.01)$ & $0.01(0.79)$ & $-0.03(-1.33)$ \\
Number of social practices & $0.01(0.63)$ & $-0.01(-0.49)$ & $0.01^{*}(1.81)$ & $0.01(0.32)$ \\
Monthly family income & $-0.05^{* *}(-2.15)$ & $-0.02(-1.29)$ & $-0.00(-0.43)$ & $0.01(0.35)$ \\
Family social relations & $0.15^{* * *}(3.04)$ & $-0.06^{* *}(-2.38)$ & $-0.00(-0.03)$ & $-0.03(-0.65)$ \\
Level of effort in job seeking & $0.01(0.11)$ & $-0.02(-0.61)$ & $0.02^{*}(1.93)$ & $0.05(1.18)$ \\
Constant & $0.83^{* * *}(4.11)$ & $0.89^{* * *}(5.79)$ & $0.12^{* *}(2.07)$ & $0.49^{* *}(2.58)$ \\
Sigma_constant & $0.33^{* * *}(8.21)$ & $0.26^{* * *}(13.31)$ & $0.18^{* * *}(20.50)$ & $0.40^{* * *}(13.54)$ \\
$N$ & 93 & 117 & 223 & 136 \\
Pseudo $R^{2}$ & 0.1239 & 0.1557 & -0.1227 & 0.0478 \\
Log likelihood & -45.484824 & -29.924551 & 53.498228 & -87.662935 \\
LR chi2(6) & 12.86 & 11.04 & 11.70 & 8.80 \\
Prob $>$ chi2 & 0.0453 & 0.0872 & 0.0691 & 0.1850 \\
\hline
\end{tabular}




\section{Analysis of the influencing factors to employment efficiency}

According to the empirical results, gender, number of scholarships, number of practices and level of effort in job seeking are not the significant influencing factors to employment efficiency, probably because the respondents in this survey are all students who are actively looking for jobs and have their own career plans. Most of these students have strong comprehensive abilities and outstanding performance in both learning and practice, so there is no obvious difference in these three aspects. There are some significant factors: the employment efficiency of regular college students is negatively correlated with the monthly family income ( $<<0.05$ ), indicating that the higher the family income, the lower their employment efficiency will be; the employment efficiency of regular college students is positively correlated with the family social relations ( $p<0.01$ ), indicating that the stronger family social relations the students have, the higher the employment efficiency will be.

Both of these factors indicate the key role of family in influencing the employment results and employment efficiency of regular college students. This shows that parents play a pivotal role in the employment process of students. The stronger the family social relations are, the higher the employment efficiency will be, which is already confirmed in some research on social capital. Many studies have proved that social capital has a strong internal relationship with an individual's employment results. A family with better social resources and pathways can provide more employment advice for children and guide them to make rational career choices. As a result, their satisfaction with the jobs after being employed and with their employment decisions will be higher.

However, the good financial situation of a family will inhibit the student' willingness to work. On the one hand, the wealth effect of high family income will make students not rely too much on their own income, so the psychological cost of quitting their jobs is lower, and they tend to resign more frequently; on the other hand, students from higher-income families tend to have higher expectations for their jobs. They can easily reduce their loyalty to their employers under the effect of peer pressure and will lower their evaluations on the employers as their understanding go deeper about them. At the same time, the negative influences from family social relations will also start to show. Compared with those from poor families, students coming from wealthier families are more likely to follow the advice of their parents, but as they start working, their employment satisfaction and willingness will get further away from their expectations, making their employment efficiency lower.

\section{Analysis of the influencing factors to job seeking efficiency}

Job seeking efficiency is a reflection of their employability previously shaped in their job seeking process on the job market. Students with high job seeking efficiency have a stronger confidence in job seeking, and it takes them less time to find jobs. According to the empirical results, the three factors - gender, number of practices and level of effort in job seeking - have significant impacts on the job seeking efficiency of regular college students. Among them, gender and job seeking efficiency are negatively correlated, indicating that the job seeking efficiency of males is lower. Some studies have also proved that females are more likely to be 
content with the status quo than males and pursue a stable working state, while males are more adventurous and willing to take challenges, so their turnover rate is naturally higher. There is a positive correlation between the number of practices and the job seeking efficiency, indicating that the more the number of practices, the higher the job seeking efficiency will be. The level of effort in job seeking is also positively correlated with the job seeking efficiency, which is in line with the actual situation. This indicates that subjective initiative, selfawareness and self-motivation are the key factors that determine the students' ability improvement behaviours and the transformation of their abilities into results.

\section{Conclusion and Implications}

E-modules must be able to overcome the limitations of time, space, and sensory power for student and teacher or both of them. It is used to improve and develop student's skills. The e-modul based on the problembased learning is able to improve the students ability especially the basic of science-level proven with the ngain results is 0,6 which is in the moderate skills category.

\section{Conclusion}

Using the DEA method combined with the Tobit model regression analysis, this paper obtains the employment efficiency and job seeking efficiency of regular college and junior college students. The DEA results reflect the common problems with applied college students - excessive input in education and insufficient output into employment, leading to general low employment efficiency and job seeking efficiency of college students. On the whole, input factors have different degrees of redundancy and output factors also show different degrees of deficiency. The employment efficiency and job seeking efficiency both being low is not the result of a single factor, but rather of multiple ones, and there are individual differences. Through the survey among regular and junior college students, this paper finds that even applied talents who well meet social needs still need to face the challenges like ordinary ones when they are looking for and choosing jobs. Factors like family financial status, gender and social capital owned have great impacts in this process, showing that colleges still have a lot to improve in helping college students establishing the right job-choosing views, building their confidence and providing them with sufficient channels for job seeking.

\section{Implications}

Help students build confidence in job seeking. The job-seeking confidence of students mainly depends on whether they have clear life goals and how extensive social experience they have. One of the key steps to help students establish their life goals is to guide them in career planning. This requires colleges to arrange the career planning training for students at a more reasonable time and frequency during their college years. To help students gain more social experience, colleges should create more favourable conditions and encourage students to participate in social practical activities so as to enhance their experience of activities, stimulate their 
potentials and cultivate their positive and optimistic attitudes towards work and life. Practical activities include activities both inside and outside campus. When carrying out such activities, colleges should intentionally adopt various incentives or mandatory rules to ensure that all students have the opportunity to participate. At the same time, by establishing files of student activities, colleges can track and record their growing process and regularly assess students' progress in confidence building, so as to effectively improve their job seeking awareness and confidence.

Enhance the "family-college" mechanism to guide students in employment. Colleges must recognize that the career anchor of a student is influenced jointly by college education and family environment, and thus they must actively build a two-way guidance mechanism involving both college and family education to help students establish a correct view on employment and career choices and find their life goals more quickly. This requires colleges to further strengthen their connections with families in education. One feasible way is to build a "college-family" interaction platform where families can understand more about colleges and colleges can also communicate their educational philosophies to families. Through this platform, the two sides can reach a consensus. The coordinated development of both sides' educational philosophies can help achieve substantial improvement in students' life values and well guide them in career planning.

Establish a high-quality talent training system based on social needs. The competitiveness of talents is the core of employment efficiency and job seeking efficiency. Competitiveness includes not only comprehensive capabilities, but also specialities. For applied colleges, how to further deepen the integration of production and education is an issue worth thinking and exploring. This requires universities and colleges to continuously explore innovative forms of college-enterprise cooperation. On the one hand, colleges should carry out teaching reforms, such as implementing the flexible credit-based system to achieve individualized training, implementing classroom reforms and exploring the new teaching operation system centred on student development; on the other hand, colleges should seek diverse forms of cooperation with enterprises to help students gain more practical experience and train their basic business thinking.

\section{References}

Alm, J., \& Winters, J.V. (2009). Distance and intrastate college student migration. Economics of Education Review, 28(6), 728-738. http://dx.doi.org/10.1016/j.econedurev.2009.06.008 •

Barrick, M.R., \& Mount, M.K. (1991). The big five personality dimensions and job performance: a metaanalysis. Personnel psychology, 44(1), 1-26. https://doi.org/10.1111/j.1744-6570.1991.tb00688.x

Chen, L., \& Wan, P.B. (2017). Gain and Loss of China's Higher Education Expansion: Evaluation on the Policy Effects in Three Major Perspectives. Chinese Journal of Population Science, (1), 115-125.

Clark, A.E. (2005). Your money or your life: Changing job quality in OECD countries. British Journal of Industrial Relations, 43(3), 377-400.

Cuyper, N.D., Mauno, S., Kinnunen, U., \& Mäkikangasb, A. (2011). The role of job resources in the relation between perceived employability and turnover intention: A prospective two-sample study. Journal of vocational behavior, 78(2): 253-263. https://doi.org/10.1016/j.jvb.2010.09.008 
Cuyper, N.D., Raeder, S., Van der Heijden, B.I.J.M., \& Wittekind, A. (2012). The association between workers' employability and burnout in a reorganization context: Longitudinal evidence building upon the conservation of resources theory. Journal of Occupational Health Psychology, 17(2), 162-174. https://doi.org/10.1037/a0027348

Cuyper, N.D., Van der Heijden, B.I.J.M., \& De Witte, H. (2011). Associations between perceived employability, employee well-being, and its contribution to organizational success: a matter of psychological contracts. The International Journal of Human Resource Management, 22(7), 1486-1503. https://doi.org/10.1080/09585192.2011.561962

Denison, E.F. (1961). Measurement of labor input: some questions of definition and the adequacy of data, Output, Input, and Productivity Measurement. Princeton University Press, 347-386.

Fugate, M., \& Kinicki, A.J. (2008). A dispositional approach to employability: Development of a measure and test of implications for employee reactions to organizational change. Journal of Occupational and Organizational Psychology, 81(3), 503-527. http://dx.doi.org/10.1348/096317907X241579

Groen, J.A. (2004). The effect of college location on migration of college educated labor. Journal of Econometrics, 121(1), 125-142. https://doi.org/10.1016/j.jeconom.2003.10.002

Hausmann, R., Hwang, J., \& Rodrik, D. (2007). What you export matters. Journal of economic growth, 12(1), $1-25$.

Heckman, J.J. (2000). Policies to foster human capital. Research in economics, 54(1), 3-56. https://doi.org/10.1006/reec.1999.0225

Heckman, J.J., \& Rubinstein, Y. (2001). The importance of noncognitive skills: Lessons from the GED testing program. American Economic Review, 91(2), 145-149. https://doi.org/10.1257/aer.91.2.145

Jorgenson, D.W., \& Griliches, Z. (1967). The explanation of productivity change. The review of economic studies, 34(3), 249-283. https://doi.org/10.2307/2296675

Kalleberg, A.L., V\& aisey, S. (2005). Pathways to a good job: perceived work quality among the machinists in North America. British Journal of Industrial Relations, 43(3), 431-454.

Knight, P. (2001). Employability and assessment, Skills plus-a paper prepared for the fourth colloquium, 3rd October. 2001

Li, R.S. (2012). On reform and practice of applied undergraduate talents cultivation mode_- Take "211" talents cultivation mode in Hubei university of arts and science as an example. Journal of Higher Education, (8), 65-70.

Lin, C.H., \& Hong C.W. (2014). Research on social crisis caused by the imbalances of college students,employment fairness and the countermeasure-Based on the perspective of government responsibility. China Higher Education Research, 33(5), 27-29.

Liu, F.X., \& Zhu, J.H. (2017). A study of the influence factors of college graduates' employment results From the perspective of human capital theory and the SCCT career development theory. Journal of Southwest University (Social Sciences Edition), 43(5), 30-37.

Liu, L., Guo, L., \& Li, J.B., Ding, S.Q. (2013). Higher education and talent gathering investments conjugate drive regional economic growth: A case study in Jiangsu and Zhejiang provinces. Economic Geography, $33(11), 15-20$. 
Lu, W.X. (2013). Vocational educational difficulty and its breakthrough of promoting highly skilled personnel's cultivation specification — Connection perspective of higher vocational education and applicationoriented undergraduate education. China Higher Education Research, (12), 97-101.

Ma, L.P., \& Pan, K.F. (2013). Stay or migrate An empirical study on the relationship between work place, university place and birth place. Tsinghua Journal of Education, 34(5), 118-124.

Nicholson, N. (1996). Towards a New Agenda for Work and Personality: Traits, Self-identity,"Strong" Interactionism, and Change Guest Editor's Introduction. Applied Psychology, 45(3), 189-205.

Rees, A. (1966). Information networks in labor markets. The American Economic Review, 56(1/2), 559-566.

Romalis, J. (2004). Factor proportions and the structure of commodity trade. American Economic Review, 94(1), 67-97. https://doi.org/10.1257/000282804322970715

Shen X.M. (2013). Based on the psychological capital of college student's employment ability training. China Higher Education Research, (12), 90-93.

Solow, R.M. (1957). Technical change and the aggregate production function. The review of Economics and Statistics, 39(3), 312-320.

Tone, K. (2001). A slacks-based measure of efficiency in data envelopment analysis. European journal of operational research, 130(3), 498-509.

Wang, D.D. (2006). Knowledge theory of production function. Social Science Front, (1), 93-100.

Wang, Y.S. (2016). Talent Cultivation Objectives of the First-Class University in China. China Higher Education Research, (8), 13-19.

Weng Q.X., Liu, J.B., Wu, S., \& Wang Q. (2016). The Relationship and Employment between Job Opportunity Recognition Competence Outcomes. Peking University Education Review, (2), 81-98. https://doi.org/10.3969/j.issn.1671-9468.2016.02.006

Winters, J.V. (2011). Human capital and population growth in nonmetropolitan US counties: The importance of college student migration. Economic Development Quarterly, 25(4), 353-365.

Wittekind, A., Raeder, S., \& Grote, G. (2010). A longitudinal study of determinants of perceived employability. Journal of Organizational Behavior, 31(4), 566-586.

Wu, Y.W., Zhao, Q. (2010). Higher education expansion and employment of university graduates. Economic Research Journal, 9, 93-108.

York, M., Knight, P. T. (2004). Embedding employability into the curriculum. Higher Education Academy, York, 2004: 4-5.

Yu, H.B., Zheng, X.M., Xu, C.Y., \& Yan, C.L. (2014). The relationships between university student's employability with subjective and objective job-search performance: Liner and invert-U relationships. Acta Psychologica Sinica, 46(6), 807-822. https://doi.org/10.3724/SP.J.1041.2014.00807

Zeng, X.Q. (2004). Job seeking of college graduates in employment environment under transition. Economic Research Journal, (6), 87-95.

Zhang, Z., \& Xu, J. (2015). The effect of China's high education expansion on college graduates' income: An empirical analysis of CHIPS data. South China Population, 30(5), 10-19.

Zhou, D.L. (2012). Technology progress, capital deepening and industry upgrading and the employment of college graduates: An empirical study on 2001 2010 panel data of the Chinese provinces. Chinese Journal of Population Science, (2), 14-24. 